\title{
Role of phototherapy, BAX gene expression in hyperbilirubinemia development in full- term neonates
}

\author{
Mohamed farouk Afifi ${ }^{1}$, Abdel Hakeem Abdel Mohsen ${ }^{1}$, Emad Abdel Naeem ${ }^{2 *}$ \\ and Marwa Ibrahem Abdel razic ${ }^{1}$
}

\begin{abstract}
Background: Phototherapy is the main therapeutic interference for neonatal hyperbilirubinemia used to escape an exchange transfusion and to decrease the risk of bilirubin-induced encephalopathy (kernikterus). Phototherapy has an oxidative effect on cell components and cell membranes by enhancing peroxidation of lipid and damage to DNA. Many genes function as apoptosis regulatory genes. Examples of these genes involve the BCL2 gene as an anti-apoptotic oncogene, and the BAX gene which is a promoter of apoptosis.

We aimed to evaluate the effect of phototherapy on expression of BAX and $\mathrm{BC} / 2$ genes in hyperbilirubinemic fullterm neonates.

Eighteen full-term neonates with indirect hyperbilirubinemia who received phototherapy for $24 \mathrm{~h}$ were enrolled as a study group and nine apparently healthy full-term neonates with a normal serum bilirubin level were included as a control group. Assessment of the anti-apoptotic effect(s) of BCL2 and the pro-apoptotic effect(s) of (Bax) genes was achieved by quantitative assay of their products (BCL2 and BAX proteins) by ELISA assay after phototherapy.
\end{abstract}

Results: Significant decrease in the bcl2 $(p<0.001)$ and increase in Bax protein $(p<0.001)$ serum levels after phototherapy in hyperbilirubinemic full-term neonates.

Conclusion: Hyperbilirubinemia has no apoptotic influence, while phototherapy induces apoptosis in the peripheral blood of hyperbilirubinemic full-term infants.

Keywords: Hyperbilirubinemic, Phototherapy, Apoptosis, bcl2 protein, Bax protein

\section{Background}

The accumulation of unconjugated, nonpolar, lipidsoluble bilirubin pigment within the skin in the first days of life results in the development of jaundice. Neonatal jaundice (the yellow coloration of the white part of the eye and skin) occurs in $60 \%$ of term infants. Although low levels of bilirubin have a physiologic antioxidant role, higher levels of unconjugated bilirubin are probably neurotoxic [1].

Over the past 50 years, phototherapy was the primary noninvasive and easily available mode of treatment of indirect hyperbilirubinemia for prevention bilirubininduced neurotoxicity in newborn babies [2]. The light

\footnotetext{
* Correspondence: emadallam_lab@yahoo.com

${ }^{2}$ Clinical Pathology Department, Minia University, El Minya, Egypt

Full list of author information is available at the end of the article
}

of the photo changes the structure of the bilirubin molecule into water-soluble isomers that excreted without the need of hepatic conjugation [3]. Phototherapy has no serious side effects. Experimental and observational studies proved some genotoxic effects [4] and may lead to degeneration of the retina, diarrhea, dehydration, and skin rash [5]. Exposure of cells to visible light could induce single or double DNA strand breaks, sister chromatid exchange, and mutations. Oxidative modifications to DNA can lead to oxidative stress-related diseases such as necrotizing enterocolitis and patent ductus arteriosus in newborn infants and even increase the risk for future cancer development [6]. Moreover, phototherapy increase apoptosis in neonatal small intestine cells and the mouse lymphoma cell line [7]. Recently, neonatal jaundice and phototherapy were found to enhance apoptosis 
of peripheral blood lymphocytes from infants with hyperbilirubinemia, mostly through downregulation of BCL2 expression and upregulation of BAX gene expression [8]. Human cells use many strategies for the protection of genomic DNA from accumulating such lesions. As extensive damage blocks the cell cycle, progression so allows more time for DNA repair. However, apoptosis occurs in irreparable damage of the affected cells [9]. Two major signaling pathways had been identified leading to apoptosis. The mitochondria-dependent is governed by suppressing or inducing genes, such as BCL2 and BAX, respectively [10]. The death receptordependent is the other one, requiring the interaction of death receptors involving Fas/Fas 1 interaction receptorassociated death proteases with successive activation of downstream effector caspases [11]. The family of BCL2 proteins compromises a critical control point in apoptosis residing immediately upstream of irreversible cellular damage, and the main member of this family, BCL2, was initially found as the defining oncogene in follicular lymphoma [12]. They link with Bax and Bak domains, divide them, inhibit their oligomerization, and block the mitochondrial apoptosis pathway. Their overexpression strongly disrupts apoptosis due to cytotoxic damage by removing of free radicals, inhibition of mitochondrial canal formation, and the release of c cytochrome [13]. There are two genes (BCL2 and P53) that manage the process of apoptosis. A high concentration of BCL2 protein protects the cell from apoptosis [14].

\section{Methods}

\section{Patients}

This is a prospective observational study was conducted on 27 neonates in the first 2 weeks of life. Eighteen of them (12 males and 6 females) had indirect hyperbilirubinemia admitted to neonatal intensive care unit (NICU), from January 2016 to December 2017, and had received intensive phototherapy based on AAP guidelines with mean postnatal age $4.2 \pm 1.9$ days. Another 9 (6 males and 3 females) apparently healthy full-term neonates with normal serum bilirubin levels were enrolled as control group, with mean postnatal age of $4.2 \pm 1.9$ days. Premature and low birth weight infants, neonates with birth asphyxia and sepsis, infants of diabetic mothers, neonates with congenital anomalies, and neonates with cholestatic jaundice all were excluded from the study. All patients and healthy controls were subjected to full perinatal history and thorough clinical examination. Complete blood count $(\mathrm{CBC})$, reticulocyte count, liver enzymes and serum albumin levels, total and direct bilirubin, and $\mathrm{RH}$ and blood group to mothers and babies all were done to enrolled neonates (Table 1).

Serum Bcl2 and serum BAX protein levels were assayed by ELISA technique. One sample was taken at
Table 1 Clinical and some laboratory parameter in hyperbilirubinemic and controls of neonates

\begin{tabular}{|c|c|c|c|}
\hline & \multicolumn{2}{|l|}{ Full-term } & \multirow{3}{*}{$\begin{array}{l}p \\
\text { value }\end{array}$} \\
\hline & Cases & Control & \\
\hline & $N=18$ & $N=9$ & \\
\hline \multicolumn{4}{|l|}{ Age } \\
\hline Range & $1-8$ & $1-7$ & 0.979 \\
\hline Mean \pm SD & $4.2 \pm 1.9$ & $4.2 \pm 1.9$ & \\
\hline Median & 4 & 4 & \\
\hline \multicolumn{4}{|l|}{ Sex } \\
\hline Male & $12(66.7 \%)$ & $6(66.7 \%)$ & 1 \\
\hline Female & $6(33.3 \%)$ & $3(33.3 \%)$ & \\
\hline \multicolumn{4}{|l|}{ Weight } \\
\hline Range & $2.4-3.9$ & $3-4$ & 0.075 \\
\hline Mean $\pm S D$ & $3 \pm 0.4$ & $3.3 \pm 0.4$ & \\
\hline \multicolumn{4}{|l|}{$\mathrm{Hb}, \mathrm{g} / \mathrm{dl}$} \\
\hline Range & $7.7-21.9$ & $14.9-17.8$ & 0.530 \\
\hline Mean $\pm S D$ & $15.2 \pm 3.2$ & $15.8 \pm 0.9$ & \\
\hline \multicolumn{4}{|l|}{ TLC } \\
\hline Range & $5.2-17.4$ & $8-15$ & 0.201 \\
\hline Mean $\pm S D$ & $9.9 \pm 3.1$ & $11.4 \pm 2.4$ & \\
\hline \multicolumn{4}{|l|}{ Platelets } \\
\hline Range & $123-769$ & $180-360$ & 0.719 \\
\hline Mean $\pm S D$ & $297.7 \pm 162.2$ & $252.8 \pm 58.4$ & \\
\hline Median & 267 & 250 & \\
\hline \multicolumn{4}{|c|}{ Reticulocyte count, \% } \\
\hline Range & $0.5-5.5$ & $0.5-2.5$ & $0.003^{*}$ \\
\hline Mean $\pm S D$ & $3 \pm 1.4$ & $1.5 \pm 0.6$ & \\
\hline Median & 2.8 & 1.7 & \\
\hline \multicolumn{4}{|l|}{$A L T, u / l$} \\
\hline Range & $15-49$ & $11-33$ & 0.458 \\
\hline Mean $\pm S D$ & $24.9 \pm 10.5$ & $22 \pm 7.3$ & \\
\hline \multicolumn{4}{|l|}{ AST, u/l } \\
\hline Range & $13-55$ & $24-40$ & 0.335 \\
\hline Mean $\pm S D$ & $35.1 \pm 10.9$ & $31.2 \pm 6.3$ & \\
\hline \multicolumn{4}{|c|}{ Albumin, mg/dl } \\
\hline Range & $3-4.9$ & $3-4.3$ & 0.600 \\
\hline Mean \pm SD & $3.8 \pm 0.5$ & $3.7 \pm 0.4$ & \\
\hline
\end{tabular}

*Significant $(p<0.05)$

the admission and another one after $24 \mathrm{~h}$ of intensive phototherapy exposure (Bilisphere 360).

\section{Sampling}

Five milliliters of peripheral venous blood was withdrawn under complete aseptic technique withdrawn before phototherapy: $1 \mathrm{ml}$ was withdrawn in EDTA 
vacutainer for $\mathrm{CBC}$ and reticulocyte count; $2 \mathrm{ml}$ was withdrawn in plain vacutainer for serum bilirubin level (total and direct bilirubin), $\mathrm{RH}$ and blood group, liver enzymes, and serum albumin level; and $2 \mathrm{ml}$ were taken in EDTA vacutainer for plasma BCL2 level and BAX protein level (human B cell leukemia/lymphoma 2 (Bcl2) ELISA Kit and human Bcl-2-associated $X$ protein (Bax) ELISA Kit).

After phototherapy, $4 \mathrm{ml}$ of peripheral blood was withdrawn, $2 \mathrm{ml}$ in EDTA vacutainer for plasma BCL2 and BAX protein level and $2 \mathrm{ml}$ withdrawn in plain vacutainer for serum bilirubin level (Table 2).

Table 2 Comparison between hyperbilirubinemic neonates and controls in full-term neonates before and after phototherapy

\begin{tabular}{|c|c|c|c|}
\hline & \multicolumn{2}{|l|}{ Full-term } & \multirow[t]{3}{*}{$p$ value } \\
\hline & Cases & Control & \\
\hline & $N=18$ & $N=9$ & \\
\hline \multicolumn{4}{|l|}{ T.B. $(\mathrm{mg} / \mathrm{dl})$ pre } \\
\hline Range & $7.6-26.1$ & $0.7-2$ & \multirow[t]{2}{*}{$<0.001^{*}$} \\
\hline Mean \pm SD & $19.6 \pm 4.7$ & $1.4 \pm 0.5$ & \\
\hline \multicolumn{4}{|c|}{ T.B. $(\mathrm{mg} / \mathrm{dl})$ post } \\
\hline Range & $5.1-20.6$ & $0.7-2$ & \multirow[t]{2}{*}{$<0.001^{*}$} \\
\hline Mean \pm SD & $14.1 \pm 4.3$ & $1.4 \pm 0.5$ & \\
\hline \multicolumn{4}{|l|}{ D.B. $(\mathrm{mg} / \mathrm{dl})$ pre } \\
\hline Range & $0.5-4.7$ & $0.1-0.5$ & \multirow[t]{3}{*}{$<0.001^{*}$} \\
\hline Mean \pm SD & $1.3 \pm 0.9$ & $0.3 \pm 0.2$ & \\
\hline Median & 1.2 & 0.3 & \\
\hline \multicolumn{4}{|c|}{ D.B. $(\mathrm{mg} / \mathrm{dl})$ post } \\
\hline Range & $0.3-8.7$ & $0.1-0.5$ & \multirow[t]{3}{*}{$<0.001^{*}$} \\
\hline Mean \pm SD & $1.6 \pm 1.8$ & $0.3 \pm 0.2$ & \\
\hline Median & 1.2 & 0.3 & \\
\hline \multicolumn{4}{|l|}{ BCL2 pre } \\
\hline Range & $206-657$ & 409-588 & \multirow[t]{2}{*}{0.310} \\
\hline Mean \pm SD & $451.2 \pm 132.6$ & $499.8 \pm 61.8$ & \\
\hline \multicolumn{4}{|l|}{ BCL2 post } \\
\hline Range & $91-572$ & 409-588 & \multirow[t]{2}{*}{$0.001^{*}$} \\
\hline Mean \pm SD & $315.3 \pm 134.1$ & $499.8 \pm 61.8$ & \\
\hline \multicolumn{4}{|l|}{ BAX pre } \\
\hline Range & $28-70$ & $28-62$ & \multirow[t]{3}{*}{0.461} \\
\hline Mean \pm SD & $49.7 \pm 11$ & $46.3 \pm 10.7$ & \\
\hline Median & & 48 & \\
\hline \multicolumn{4}{|l|}{ BAX post } \\
\hline Range & $58-96$ & $28-62$ & \multirow[t]{3}{*}{$<0.001^{*}$} \\
\hline Mean \pm SD & $76.3 \pm 9.6$ & $46.3 \pm 10.7$ & \\
\hline Median & & 48 & \\
\hline
\end{tabular}

*Significant $(p<0.05)$

\section{Phototherapy}

The type of phototherapy used in the study is intensive phototherapy systems which consisted of 12 white fluorescent tubes (Philips TL03, Ontario, Canada) placed within $20 \mathrm{~cm}$ under and above the infant's front and back. The infants were put naked, excluding a diaper and eye patches, in an incubator or intensive phototherapy unit (Bilicrystal, Medes-time, or Bilisphere 360, Marcinelle, Belgium). The light energy of the phototherapy units was $30-34 \mu \mathrm{W} \mathrm{cm}-2 \mathrm{~nm}-1$ in the $430-490-\mathrm{nm}$ band. Phototherapy was uninterrupted to jaundiced neonates except during feeding and care.

\section{Bcl2 protein assaying}

This kit from the Philippines uses enzyme-linked immune sorbent assay (ELISA) based on biotin double antibody sandwich technology to assay human B cell leukemia/lymphoma 2 (Bcl-2), by adding $\mathrm{B}$ cell leukemia/lymphoma $2(\mathrm{Bcl}-2)$ to wells that are precoated with B cell leukemia/lymphoma 2 (Bcl-2) monoclonal antibody and then incubated at $37^{\circ} \mathrm{C}$ for $60 \mathrm{~min}$. After incubation, anti-B cell leukemia/lymphoma 2 (Bcl2) antibodies labeled with biotin to unite with streptavidin-HRP were added, which forms the immune complex (adding $50 \mu \mathrm{l}$ standard and streptomycin-HRP $50 \mu \mathrm{l}, 40 \mu \mathrm{l}$ sample, and then $10 \mu \mathrm{l} \mathrm{Bcl}-2$ antibodies, $50 \mu \mathrm{l}$ streptavidin-HRP; then covering it with seal plate membrane, shaked gently to mix). Removing unbound enzymes after incubation and washing, then adding $50 \mu \mathrm{l}$ chromogen solution A to each well and then add $50 \mu \mathrm{l}$ chromogen solution $\mathrm{B}$ to each well, shaked gently to mix and incubated for $10 \mathrm{~min}$ at $37^{\circ} \mathrm{C}$ away from light for color development were done. The solution turned blue and changed to yellow with the effect of acid. The shades of the solution and the concentration of human B cell leukemia/lymphoma 2 (Bcl-2) are positively correlated [15].

\section{BAX protein assaying}

This kit from the Philippines uses enzyme-linked immune sorbent assay (ELISA) based on biotin double antibody sandwich technology to assay human Bcl-2 associated $\mathrm{X}$ protein (Bax). Add Bcl-2 associated X protein $(\mathrm{Bax})$ to wells that are pre-coated with $\mathrm{Bcl}-2$ associated $\mathrm{X}$ protein (Bax) monoclonal antibody and then incubated at $37^{\circ} \mathrm{C}$ for $60 \mathrm{~min}$. After incubation, add anti-Bcl2 associated $\mathrm{X}$ protein (Bax) antibodies labeled with biotin to unite with streptavidin-HRP, which forms the immune complex (adding $50 \mu \mathrm{l}$ standard and streptomycinHRP $50 \mu \mathrm{l}, 40 \mu \mathrm{l}$ sample and then $10 \mu \mathrm{l}$ Bax antibodies, $50 \mu \mathrm{l}$ streptavidin-HRP). Remove unbound enzymes after incubation and washing, then add $50 \mu \mathrm{l}$ chromogen solution A to each well, and then add $50 \mu \mathrm{l}$ chromogen solution B to each well. Shake to mix. Then incubate for 10 
min at $37^{\circ} \mathrm{C}$ away from light. The solution will turn blue and change to yellow with the effect of acid. The shades of the solution and the concentration of human Bcl-2associated X protein (Bax) are positively correlated [15].

\section{Statistical analysis}

The gathered data were coded, tabulated, and statistically analyzed using SPSS program (Statistical Package for Social Sciences) software version 25. Parametric quantitative data were expressed by mean, standard deviation, and minimum and maximum of the range. Nonparametric data were expressed by a median, while for absolute data by number and percentage. Independent samples $T$ test was used for comparison between two parametric groups, Mann-Whitney test for nonparametric groups, paired sample $T$ test for parametric quantitative data between the two times within each group and Wilcoxon signed-rank test for nonparametric quantitative data. Fisher's exact test (if expected number per cell $<5$ ) qualitative data using and chi-squared test (if expected number per cell $>5$ ) were used. Correlation between laboratory data was done using Pearson's correlation coefficient. The level of significance was taken at $(p<0.05)$.

\section{Results}

Clinical and laboratory data did not differ between groups regarding $\mathrm{CBC}$, liver enzymes, and serum albumin levels while reticulocyte count was significantly increased in hyperbilirubinemic neonates before phototherapy compared to controls $(3 \pm 1.4$ vs $1.5 \pm 0.6, p=0.003)$. There is a significantly higher level of total and direct bilirubin $(p<$ 0.001 ) before and after phototherapy in hyperbilirubinemic full-term neonates when compared with controls.
There was no significant difference in bcl2 and Bax protein levels before phototherapy $(p>0.05)$ between hyperbilirubinemic full-term neonates and controls. There is a significant decrease in the serum levels of bcl2 after phototherapy $(p<0.001)$ (Fig. 1) and serum levels of Bax protein after phototherapy $(p<0.001)$ (Fig. 2). There was a significantly positive correlation between serum levels of Bcl2 and total bilirubin after phototherapy $(r=0.702, p<$ 0.001 ) while a significantly negative correlation was found after phototherapy $(r=-0.846, p<0.001)$ (Table 3$)$.

\section{Discussion}

There was no significant difference in BCL2 and Bax serum levels between hyperbilirubinemic full-term neonates and controls before phototherapy. Also, there was no significant correlation between total bilirubin, BCL2, and bax protein before phototherapy, so hyperbilirubinemia did not influence apoptosis in the peripheral blood of hyperbilirubinemic full-term neonates. The serum level of BCL2 protein was lower between the cases before phototherapy compared to controls explaining that bilirubin and phototherapy had genotoxic effects [8]. A high level of bilirubin may conduct to oxidative damage in newborns as photochemical reactions may produce toxic photoproducts, probably peroxides $[16,17]$, agreeing the results of Yahia et al [18] that found no significant difference in P53 level (marker of apoptosis) in the tested groups before exposure to phototherapy. Hyperbilirubinemia lacks the ability to induce any genotoxic effects on DNA in jaundiced neonates. Bilirubin has a major physiological antioxidant role, responsible for its cytoprotective feature mediated by its sacrificial oxidation [19]. After phototherapy, lower serum compared to their levels before and serum levels of bax proteins were

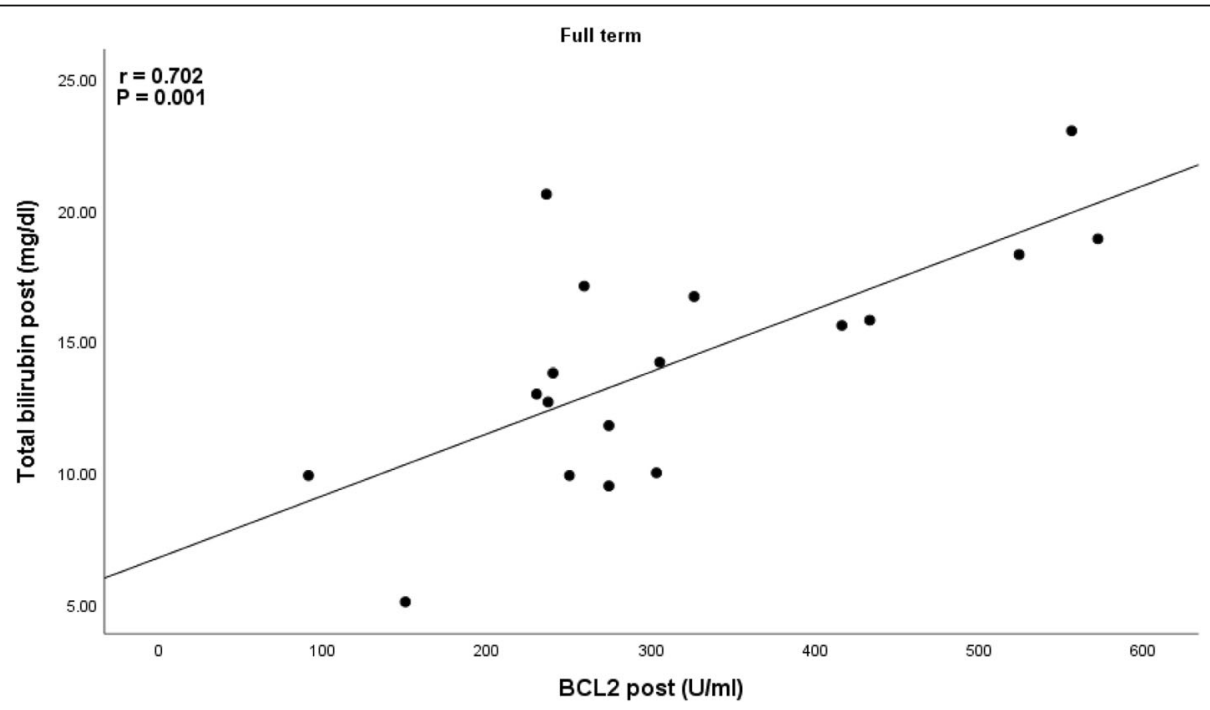

Fig. 1 Correlation of serum levels of BCL2 protein and total bilirubin in hyperbilirubinemic full-term neonates after phototherapy 


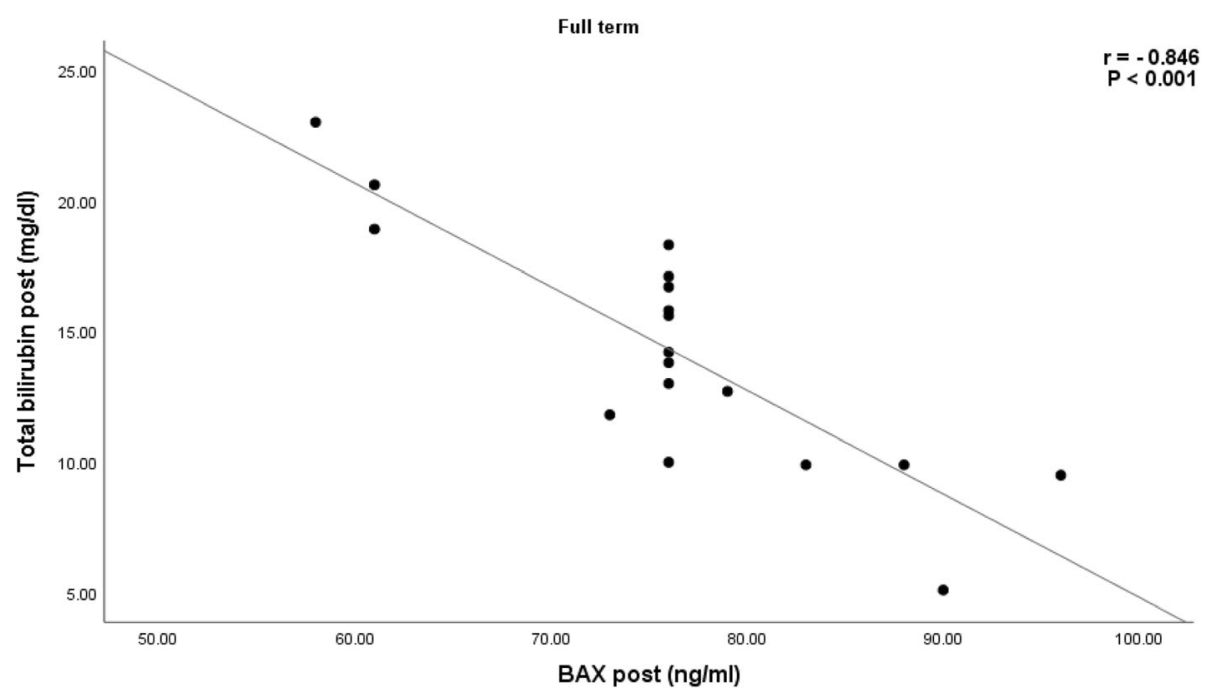

Fig. 2 Correlation of serum levels of Bax protein and total bilirubin in hyperbilirubinemic full-term neonates after phototherapy

significantly higher compared to their levels before; in hyperbilirubinemic full-term neonates, all can be attributed to an increase in DNA damage and a concomitant increase of rate of apoptosis, clarified by BCL2 downregulation and increased BAX gene expression. Also, P53 levels significantly increase after exposure to phototherapy $[8,18]$. PUVA phototherapy influences evident downregulation of BCL2 level and produces early significant depletion of epidermal and dermal $\mathrm{T}$ cells in psoriatic tissues by the induction of apoptosis [20]. The

Table 3 Comparison between hyperbilirubinemic full-term neonates before and after phototherapy as regard to total and direct bilirubin, serum levels of BCL2 protein, and serum levels of Bax protein

\begin{tabular}{|c|c|c|c|}
\hline & \multicolumn{2}{|l|}{ Full-term cases } & \multirow[t]{2}{*}{$p$ value } \\
\hline & Pre & Post & \\
\hline \multicolumn{4}{|l|}{ T.B. } \\
\hline Range & $7.6-26.1$ & $5.1-20.6$ & $<0.001^{* *}$ \\
\hline Mean \pm SD & $19.6 \pm 4.7$ & $14.1 \pm 4.3$ & \\
\hline \multicolumn{4}{|l|}{ D.B. } \\
\hline Range & $0.5-4.7$ & $0.3-8.7$ & 0.447 \\
\hline Mean \pm SD & $1.3 \pm 0.9$ & $1.6 \pm 1.8$ & \\
\hline Median & 1.2 & 1.2 & \\
\hline \multicolumn{4}{|l|}{ BCL2 } \\
\hline Range & $206-657$ & $91-572$ & $<0.001^{* *}$ \\
\hline Mean \pm SD & $451.2 \pm 132.6$ & $315.3 \pm 134.1$ & \\
\hline \multicolumn{4}{|l|}{ BAX } \\
\hline Range & $(28-70)$ & (58-96) & $<0.001^{* *}$ \\
\hline Mean \pm SD & $49.7 \pm 11$ & $76.3 \pm 9.6$ & \\
\hline Median & & & \\
\hline
\end{tabular}

$p$ value is considered significant if less than 0.05 , **Highly significant effects of phototherapy noted were increased in the apoptosis of polymorphonuclear cells which leads to a decreased number of neutrophil anti-apoptotic factors and neutrophils in areas of inflammation [21].

The critical difference can be justified by different stages of apoptosis process and duration. The P53 level and plasma $\mathrm{Bcl}-2$ and $\mathrm{BAX}$ gene expression are signals affecting apoptotic responses, and any changes in their levels are associated with apoptosis. Moreover, the duration of apoptosis may range from 12 to $24 \mathrm{~h}$, depending on the stimulant and cell type [22, 23]. Another interesting study demonstrated that hyperbilirubinemia is not associated with DNA strand breaks, which are a wellknown type of DNA damage; both conventional and intensive phototherapy treatments increased damage to DNA. The duration, but not the strength, of phototherapy correlates with the extent of DNA damage [24].

Phototherapy, although decreasing hyperbilirubinemia, may cause oxidative injury to the red cell membrane and increases the levels of lipid peroxidation products. Excess amounts of free oxygen radicals can induce injury to host cells and may influence DNA strand breaks [25]. Finally, the hematopoietic system, particularly the lymphoid lineage, is very vulnerable to DNA damage and organisms depend on apoptosis for the removal of damaged cells. Excess BCL2 beats the apoptosis influencing the effect of P53 protein, so the alleviation of cell cycle stopped by a decreased level of BCL2, potentiates P53-induced apoptosis [26].

\section{Limitation}

Our study has some limitations that require consideration. We did not use conventional phototherapy so we cannot decide if the intensity of phototherapy has a role 
or not. Only one blood sample after $24 \mathrm{~h}$ of exposure could be taken so we cannot decide if the duration has extensive damage or not.

\section{Conclusion}

Hyperbilirubinemia does not affect apoptosis but intensive phototherapy can do in full-term neonates as there were downregulation of anti-apoptotic protein (bcl2) and upregulation of the pro-apoptotic protein (Bax).

\section{Abbreviations}

AAP: American Academy of Pediatrics; BAD: BCL-2-associated death promoter protein; Bak: BCL-2 homologous antagonist/killer protein; Bax: BCl2-associated X protein; BCl2: B cell leukemia/lymphoma 2; CBC: Complete blood count; DNA: Deoxyribonucleic acid; EDTA: Ethylenediaminetetraacetic acid; ELISA: Enzyme-linked immune sorbent assay; NICU: Neonatal intensive care unit; PUVA: Psoralen plus ultraviolet A; SPSS: Statistical Package for Social Sciences

\section{Acknowledgements}

The corresponding author would like to acknowledge the participants and the supporting staff in this study for their immense support.

\section{Authors' contributions}

All authors contributed to the data interpretation and manuscript writing MA, and AA conceptualized designed the study and contributed to the data interpretation. EA supervised the laboratory analysis. MR contributed to the conceptualization and the writing of the drafted manuscript and selected cases and clinical data collection. All authors read and approved the final manuscript.

\section{Funding}

This research did not receive any specific grant from funding agencies in the public, commercial, or not-for-profit sectors.

\section{Availability of data and materials}

The datasets used and/or analyzed during the current study are available from the corresponding author on reasonable request.

\section{Ethics approval and consent to participate}

The study was conducted according to the principle Helsinki and was approved by the scientific ethics committee of the Faculty of Medicine, Minia University approval no (205:4/2019). Written informed parental consent was obtained for each patient before enrollment.

\section{Consent for publication}

Not applicable

\section{Competing interests}

The authors declare that they have no competing interests.

\section{Author details}

${ }^{1}$ Pediatric Department, Minia University, El Minya, Egypt. ${ }^{2}$ Clinical Pathology Department, Minia University, El Minya, Egypt.

Received: 4 September 2019 Accepted: 25 October 2019

Published online: 31 January 2020

\section{References}

1. Ambalavanan N, Carlo WA (2015) Jaundice and hyperbilirubinemia in the newborn. In: Kliegman RM (ed) Nelson text book of pediatrics (20th edn). Elsevier Inc, p 871

2. Hansen TW (2010) Twists and turns in phototherapy for neonatal jaundice. Acta Paediatr 99:1117-1118

3. Tatli MM, Minnet C, Kocyigit A, Karadag A (2008) Phototherapy increases DNA damage in lymphocytes of hyperbilirubinemic neonates. Mutat Res 654:93-95
4. Aycicek A, Kocyigit A, Erel O, Senturk H (2008) Phototherapy causes DNA damage in peripheral mononuclear leukocytes in term infants. J Pediatr(Rio J) 84:141-146

5. Karakukcu C, Ustdal M, Ozturk A, Baskol G, Saraymen R (2009) Assessment of DNA damage and plasma catalase activity in healthy term hyperbilirubinemic infants receiving phototherapy. Mutat Res 680:12-16

6. Gathwala G, Sharma S (2000) Oxidative stress, phototherapy and the neonate. Indian J Pediatr 67:805-808

7. Tanaka K, Hashimoto H, Tachibana T, Ishikawa H, Ohki T (2008) Apoptosis in the small intestine of neonatal rat using blue light-emitting diode devices and conventional halogen-quartz devices in phototherapy. Pediatr Surg Int 24:837-842

8. El-Abdin MYZ, El-Salam MA, Ibrhim MY, Koraa SSM, Mahmoud E (2012) Phototherapy and DNA changes in full-term neonates with hyperbilirubinemia. Egypt J Med Hum Genet 13:29-35

9. Hoeijmakers JH (2001) Genome maintenance mechanisms for preventing cancer. Nature 411:366-374

10. Brunner T, Mogil R, LaFace D, Yoo N, Mahboubi A, Echeverri F, Martin S, Force W, Lynch D, Ware C, Green D (1995) Cellautonomous Fas (CD95)/Fasligand interaction mediates activation-induced apoptosis in T-cell hybridomas. Nature 373:441-444

11. Hockenberyt D, Nunez G, Milliman C et al (1990) BCl-2 is an inner mitochondrial membrane protein that blocks programmed cell death. Nature 348:334-336

12. Danial N (2007) BCL-2 family proteins: critical checkpoints of apoptotic cell death. J Biol Chem 285:13678-13684

13. Borner C (2003) The Bcl-2 protein family: sensors and checkpoints for life-ordeath decisions. Mol Immunol 39:615-647

14. Korsemeyer SJ (1992) Bcl-2; an antidote to programmed cell death. Cancer Surv 15:105-118

15. GenAsia Biotech Co.,Ltd 2013.

16. Nagata S, Tanaka M (2018) Programmed cell death and the immune system Nat Rev Immunol 17:153-340

17. Krakukcu C, Ustdal M, Ozturk A et al (2009) Assessment of DNA damage and plasma catalase activity in healthy term hyperbilirubenemic infant receiving phototherapy. Mutat Res 680:12-16

18. Yahia S, Shabaan AE, Gouida M, El-Ghanam D, Eldegla H, El-Bakary A, AbdelHady H (2014) Influence of hyperbilirubinemia and phototherapy on markers of genotoxicity and apoptosis in full-term infants. Eur J Pediatr 174(4):459-464

19. Seyed Alireza Mesbah-Namin SA, Maryam Shahidi M, Nakhshab M (2017) An increased genotoxic risk in lymphocytes from phototherapy-treated Hyperbilirubinemic neonates. Iran Biomed J 21(3):182-189

20. ElHadidi H, Huntar N, Zuyed A, El Mahgoub D, Nagui N, El Eishie N, Hindawy A (2008) The effect of PUVA phototherapy on Bcl-2 expression in psoriasis vulgaris. J Egypt Worn Dermarol Soc 5(2):65-69

21. Morgan MC, Rashid MR (2009) The effect of phototherapy on neutrophils. Int Immunopharmacol 9(4):383-388

22. Kerr JF, Wyllie AH, Currie AR (1972) Apoptosis: a basic biological phenomenon with wide-ranging implications in tissue kinetics. $\mathrm{Br} J$ Cancer 26(4):239-257

23. Mohamed WW, Niazy WH (2012) Genotoxic effect of phototherapy in term newborn infants with hyperbilirubinemia. J Neonat-Perinat Med 5(4):381387

24. Ramy N, Ghany EA, Alsharany W, Nada A, Darwish RK, Rabie WA, Aly H (2016) Jaundice, phototherapy and DNA damage in full-term neonates. J Perinatol 36:132-136

25. Atici A, Bozkurt A, Muslu N, Eskandari HG, Turhan AH (2009) Oxidative stress under phototherapy. Turk J Pediatr 18:259-263

26. Mohammad RM, Goustin AS, Aboukameel A et al (2007) Preclinical studies of TW-37, a new nonpeptidic small-molecule inhibitor of $\mathrm{BCl}-2$, in diffuse large cell lymphoma a xenograft model reveal drug action on both $\mathrm{BCl}-2$ and Mcl-1. Clin Cancer Res 13:2226-2235

\section{Publisher's Note}

Springer Nature remains neutral with regard to jurisdictional claims in published maps and institutional affiliations. 